\title{
REVIEW
}

\section{B cell regulation in cancer and anti-tumor immunity}

\author{
Anushruti Sarvaria, J Alejandro Madrigal and Aurore Saudemont
}

The balance between immune effector cells and immunosuppressive cells and how this regulates the tumor microenvironment has been well described. A significant contribution of immune regulatory cells, including regulatory $\mathrm{T}$ cells, to tumor progression has been widely reported. An emerging body of evidence has recently recognized a role for $B$ cells in modulating the immune response to tumors and lymphoid malignancies. Regulatory $B$ cells (Bregs) are a newly designated subset of B cells that have been shown to play a pivotal role in regulating immune responses involved in inflammation, autoimmunity and, more recently, cancer. Bregs can suppress diverse cell subtypes, including T cells, through the secretion of anti-inflammatory mediators, such as IL-10, and can facilitate the conversion of $T$ cells to regulatory $T$ cells, thus attenuating anti-tumor immune responses. Similar B-cell subpopulations have been reported to be recruited to the tumor but to acquire their immunosuppressive properties within the tumor bed and thereby attenuate anti-tumor immune responses. However, despite a pivotal role for Bregs in promoting inflammation and carcinogenesis, the phenotypic diversity of the cell surface markers that are unique to Bregs remains unclear in mice and humans. In this review, we summarize the characteristics of Bregs and review our current knowledge of Bregs and their inhibition of anti-tumor immune responses in murine tumor models and cancer patients.

Cellular \& Molecular Immunology (2017) 14, 662-674; doi:10.1038/cmi.2017.35; published online 19 June 2017

Keywords: cancer; immunotherapy; regulatory B cells

\section{INTRODUCTION}

The dynamic relationship between the immune system and cancer development has been well described over the past few decades. The tumor cell microenvironment plays a crucial role in modulating immune responses during cancer progression. ${ }^{1,2}$ Although current immunotherapeutic strategies focus extensively upon the augmentation of T-cell-mediated immunity, B cells are increasingly being appreciated as crucial players in cancer therapies. ${ }^{3}$

Peripheral B cells are identified by an array of phenotypic surface markers, which are used to divide them into various subsets (Table 1) in both mouse and human studies. ${ }^{4-7}$ These include transitional, 'immature,' B cells, which mature within the splenic microenvironment into cells that form the basis of adaptive humoral immunity: naive follicular B cells, germinal center B cells, memory B cells and antibody-secreting plasmablasts and plasma cells. ${ }^{6-11}$ In addition to these conventional B cells, there are marginal zone (MZ) B cells, which may represent a type of memory $\mathrm{B}$ cell that produce responses against blood-borne pathogens. ${ }^{11,12}$
In recent years, in addition to the well-established role of regulatory $\mathrm{T}$ cells (Tregs) in shaping anti-tumor immunity, ${ }^{13} \mathrm{a}$ new wave of research has described an emerging role for B cells with immunosuppressive and/or regulatory functions in modulating anti-tumor immune responses and in carcinogenesis. ${ }^{14-18}$ Conversely, in several studies of murine cancer models and human tumors, B cells have been shown to possess a protective rather than an immunosuppressive function. ${ }^{19-21}$ Hence, B-cell subsets with distinct phenotypes and functions may possess diverse roles in relation to antitumor responses. In this review, we focus on regulatory B cells (Bregs) and their functions in cancer.

\section{CHARACTERISTICS OF REGULATORY B CELLS}

B cells are classically known to positively modulate immune responses and inflammation through antibody production and to promote T-cell activation and proliferation through antigen presentation. ${ }^{9}$ However, over the past decade, studies have provided well-founded evidence in both mice and humans of discrete subsets of immunoregulatory $\mathrm{B}$ cells. $^{22-28}$ These

Anthony Nolan and University College London, London, UK

Correspondence: Dr A Sarvaria, Anthony Nolan Research Institute, Fleet Road, NW3 2QG London, UK.

E-mail: anushruti.sarvaria@anthonynolan.org

Received: 26 November 2016; Revised: 18 April 2017; Accepted: 18 April 2017 
Table 1 Phenotypic characterization of mouse and human peripheral B-cell subsets

\begin{tabular}{|c|c|c|c|}
\hline Subsets & Mouse phenotype & Human phenotype & Ascribed function \\
\hline Transitional & $\begin{array}{l}\text { CD19+B220+CD93+lgMhiAA4.1+ } \\
\text { CD24hiHSAhighCD21-BR3+TACI+ }\end{array}$ & $\begin{array}{l}\text { CD19+CD20+CD27-CD10+CD24high } \\
\text { CD38high IgD+CD5+BR3+ }\end{array}$ & Precursor to mature naive \\
\hline Memory & $\begin{array}{l}\text { CD19+B220+CD38+CD73+ } \\
\text { CD80+PD-L2+ }\end{array}$ & CD19+CD20+CD27+CD38 & $\begin{array}{l}\text { Recall responses and provide humoral } \\
\text { immunity }\end{array}$ \\
\hline $\begin{array}{l}\text { Antibody- } \\
\text { secreting cells }\end{array}$ & $\begin{array}{l}\text { CD19low/-B220+CD38CD138+CD93 } \\
\text { +MHCII+Ki67+(plasmablasts) } \\
\text { CD19lowB220-ID - TACI+CD38- } \\
\text { CD138highCD93+ (Plasma cells) }\end{array}$ & $\begin{array}{l}\text { CD19+CD20CD27+CD38high lgDCD138- } \\
\text { (plasmablasts) } \\
\text { CD19+CD20-lgDCD27highCD38highCD2 } \\
\text { 4loCD138high TACl+ (plasma cells) }\end{array}$ & Antibody secretion \\
\hline
\end{tabular}

Major surface marker differences between pre-immune and antigen experienced B-cell subsets. Adapted from refs 4-11.

suppressor B cells have the capacity to maintain immune tolerance and to suppress pathological autoimmune and inflammatory immune responses, as well as to suppress responses during cancer immune surveillance, through the release of anti-inflammatory mediators, such as interleukin-10 (IL-10) and the expression of inhibitory molecules, such as PD-L1. ${ }^{23-30}$

The concept that suppressor B cells orchestrate immune modulation was first suggested nearly 40 years ago, when guinea-pig-derived splenocytes depleted of B cells were associated with the increased severity and duration of contact hypersensitivity, suggesting that B cells had the capacity to inhibit T-cell activation. ${ }^{31,32}$ These findings were later supported by a series of in vivo studies, in the late 1990s, showing that the adoptive transfer of activated splenic B cells induced tolerance and the differentiation of $\mathrm{T}$ cells into suppressor $\mathrm{T}$ cells in naive recipient mice ${ }^{33,34}$ After these seminal observations, which designated a role for suppressor B cells in immune tolerance, the term 'regulatory B cells' (Bregs) was not coined until nearly 30 years later, by Mizoguchi and Bhan. ${ }^{35}$ Mizoguchi et al identified a population of gutassociated, IL-10-producing, CD1d-expressing B cells that suppressed the progression of colitis-related intestinal inflammation by downregulating inflammatory cascades. ${ }^{35}$ However, despite considerable progress in subsequent years toward showing a role for Bregs in the suppression of inflammatory responses in various models of disease, the phenotypic diversity of the cell surface markers that are unique to Bregs in mice and humans has remained unclear.

\section{Mouse Breg subsets}

Evidence that mouse Bregs exhibit immunoregulatory properties was initially illustrated in models of experimental autoimmune encephalomyelitis (EAE), ${ }^{36}$ chronic intestinal inflammation $^{35}$ and collagen-induced arthritis, ${ }^{22,37}$ where the presence of IL-10-producing splenic B cells was associated with suppressed inflammatory cascades and reduced disease pathology, whereas their absence led to excessive inflammation and exacerbated disease progression. ${ }^{22,35-37}$

Although various approaches have led to the identification of murine Breg subsets (Table 2), lack of a common phenotype with which to define Bregs has limited their study. Of the different immunosuppressive Breg subsets that have been identified in mice, Tedder and colleagues classified a unique subset of IL-10-producing $\mathrm{CD} 1 \mathrm{~d}^{\text {high }} \mathrm{CD}^{+}$B cells (B10 cells) that in mice and humans predominantly reside in the spleen. $^{23,30}$ However, B10 cells are also distributed in gutassociated lymphoid tissues, including the peritoneal cavity and mesenteric lymph nodes. ${ }^{23,36,45,46}$ The greatest frequencies of B10 cells in the peritoneal cavity were identified within the $\mathrm{CD}^{+} \mathrm{CD} 11 \mathrm{~b}^{+} \mathrm{B} 1 \mathrm{a}$ B-cell subset $(38 \%)$ followed by the CD5 ${ }^{-} \mathrm{CD} 11 \mathrm{~b}^{+} \mathrm{B} 1 \mathrm{~b}(18 \%)$ and the $\mathrm{CD}^{-} \mathrm{CD} 11 \mathrm{~b}^{-} \mathrm{B} 2$ (4\%) subsets. Peritoneal cavity $\mathrm{B} 10$ cells have been reported to regulate immune homeostasis within gut tissues by modulating $\mathrm{CD} 4^{+}$ $\mathrm{T}$-cell function and neutrophil infiltration in induced models of colitis. ${ }^{45}$ B10 cells within other mucosal tissues constitute approximately $4 \%$ of the lamina propia, $3 \%$ of Peyer's patch $\mathrm{B}$ cells and $1 \%$ of the mesenteric lymph nodes. In addition, 3-8\% of B10 cells have also been identified in the lymph nodes and peripheral blood. ${ }^{46,47}$

B10 cells have been shown to limit disease progression in EAE and in other murine models, including of arthritis, lupus and intestinal inflammation, via IL-10 secretion $^{24,35-37}$ and via cognate interactions with $\mathrm{CD} 4^{+} \mathrm{T}$ cells mediated through IL-21 and CD40. ${ }^{48}$ B10 cells also share phenotypic features with CD $19^{+} \mathrm{CD} 21^{\text {hi }} \mathrm{CD} 23^{\text {hi }} \mathrm{CD} 24^{\text {hi }}{ }_{\text {IgD }}{ }^{\text {hi }}$ IgM ${ }^{\text {hi }}$ CD $1 d^{\text {hi }}$ transitional type 2 marginal zone precursor (T2-MZP) B cells and CD1d ${ }^{\text {hi } C D 23-I g M ~}{ }^{\text {hi }} \mathrm{CD} 1 \mathrm{~d}^{\text {hi }} \mathrm{MZ}$ B cells, but they do not exclusively belong to these B-cell subpopulations. ${ }^{23,38,49}$ The adoptive transfer of MZ and T2-MZP Bregs has been shown to limit the progression of lupus ${ }^{24}$ and arthritis ${ }^{40,49}$ by reducing the $T_{h} 1 / T_{h} 17$ cell frequencies and increasing the Treg 
Table 2 Phenotypic characteristics of Mouse regulatory B-cell subsets

\begin{tabular}{|c|c|c|c|}
\hline Breg Type & Phenotype & Key feature & Reference \\
\hline B10 & CD5+CD1d $d^{\text {hi }}$ & $\begin{array}{l}\text { Found in mice spleen produce IL-10, and suppress effector CD4+ T-cell } \\
\text { and monocytes function }\end{array}$ & 23,26 \\
\hline $\mathrm{MZ}$ & CD19+CD21 hicD23-CD24 ${ }^{\text {hi }} \operatorname{lgM}^{\text {hi }} \operatorname{lgD}^{\text {lo }}$ CD1 $\mathrm{d}^{\text {hi }}$ & $\begin{array}{l}\text { Found in spleen, produce IL-10, induce Treg cells and suppress effector } \\
\text { CD8+ and CD4+ T cells }\end{array}$ & 38,39 \\
\hline T2-MZP cells & CD19+CD21 hi CD23 $3^{\text {hi }}$ & $\begin{array}{l}\text { Produce IL-10, found in spleen, induce Treg cells and suppress effector } \\
\text { CD8+ and CD4+ T cells }\end{array}$ & $18,37,40$ \\
\hline Tim-1+B cells & Tim-1+CD19+ & Produce IL-10, found in mice spleen and suppress effector CD4+ T cells & 41 \\
\hline Plasma cells & $\mathrm{CD} 138+\lg \mathrm{M}+\mathrm{CD} 1 \mathrm{~d}^{\text {hi }} \mathrm{CXCR} 4+\mathrm{MHC}-11^{\mathrm{lo}}$ & $\begin{array}{l}\text { Produce IL-10 and IL-35, found in spleen suppress NK cells, neutrophils } \\
\text { and effector CD4+ T cells }\end{array}$ & 42 \\
\hline Plasmablast & CD138+CD44 $4^{\text {hi }}$ & Produce IL-10, found in dLNs and suppress DCs and effector CD4+ T cells & 43 \\
\hline $\begin{array}{l}\text { GIFT-15 B } \\
\text { cells }\end{array}$ & $\begin{array}{l}\mathrm{B} 220+\mathrm{CD} 21+\mathrm{CD} 22+\mathrm{CD} 23+\mathrm{CD} 24+\mathrm{CD} 1 \mathrm{~d}+ \\
\mathrm{CD} 138+\operatorname{lgD}+\operatorname{lgM}+\end{array}$ & $\begin{array}{l}\text { GMCSF and IL-15 induced IL-10 secreting Bregs that suppressed IFN-y } \\
\text { responses }\end{array}$ & 44 \\
\hline $\begin{array}{l}\text { PD-L1hi B } \\
\text { cells }\end{array}$ & PD-L1 hi CD19+B220+ & $\begin{array}{l}\text { Regulated humoral responses by CD4+CXCR5+PD-1+ follicular helper } \\
\mathrm{T} \text { cells }\end{array}$ & 30 \\
\hline
\end{tabular}

Abbreviations: Breg, regulatory B cell; DC, dendritic cell; dLN, draining lymph node; MHC, major histocompatibility complex; MZ, marginal zone; NK, natural killer; T2-MZP, transitional 2 marginal zone precursor.

frequencies as a result of IL-10 secretion. ${ }^{40}$ Similarly, a subset of $\mathrm{B} 10$ cells that is $\mathrm{IgM}^{\text {hi }} \mathrm{CD} 1 \mathrm{~d}^{\text {hi }} \mathrm{CD} 5^{+} \mathrm{CD} 19^{\text {hi }} \mathrm{CD} 23^{\text {low }} \mathrm{CD} 38$ ${ }^{\mathrm{hi}} \mathrm{B} 220^{\mathrm{hi}}$ and is capable of differentiating into IgM- and IgGsecreting $\mathrm{CD}_{138^{+}}$plasma cells has also been reported. ${ }^{50}$ $\mathrm{CD} 138^{+} \mathrm{B}$ cells have been shown to confer protection in various murine models, including EAE, experimental autoimmune uveitis, models of colitis, and Salmonella infection, through the production of IL-10 and IL-35. ${ }^{42,50}$ More recently, IL-10-producing plasmablasts $\left(\mathrm{CD} 19^{+} \mathrm{CD} 138^{+}\right)$in the draining lymph nodes of mice have also been reported to exhibit suppressive capacity. ${ }^{43}$

Furthermore, in the increasing list of phenotypic markers associated with murine Bregs are CD9, ${ }^{51}$ Tim- $1^{41}$ and PD-L1. ${ }^{30}$ PD-L1-expressing B cells have been shown to inhibit tumordirected cytotoxic T-cell functions, ${ }^{52}$ reduce the expansion of $\mathrm{CD}^{+}{ }^{+} \mathrm{CXCR}^{+} \mathrm{PD}-1^{+}$follicular $\mathrm{T}$ helper cells and reduce the severity of EAE in mice through IL-10 production. ${ }^{30}$ A recent study has also shown an immunosuppressive population of $\mathrm{CD} 9^{+} \mathrm{CD} 3^{+}$adenosine-producing Breg cells that limit the severity of colitis ${ }^{53}$ and inhibit effector T-cell activation by utilizing adenosine and IL-10. ${ }^{54}$ Owing to its critical role in mediating Breg suppression, IL-10 secretion is largely, but not exclusively, used as a marker for Breg study.

\section{Human Breg subsets}

In recent years, several studies have made remarkable progress toward identifying discrete human Breg subsets that are involved in the maintenance of immune tolerance (Table 3).

Tedder and colleagues identified a population of human IL-10-producing Bregs named B10 cells, which are akin to murine B10 cells, and these cells suppress monocyte proliferation and cytokine production and are enriched within the $\mathrm{CD} 24^{\text {hi }} \mathrm{CD} 27^{+}$memory B-cell population in peripheral blood. ${ }^{26}$ In contrast, Mauri and colleagues have elegantly described an enriched population of IL-10-producing B cells within the $\mathrm{CD} 19^{+} \mathrm{CD} 24^{\mathrm{hi}} \mathrm{CD} 38^{\text {hi }}$ B-cell compartment, a phenotype that is typically characteristic of immature, transitional, $\mathrm{B}$ cells in peripheral blood. ${ }^{25,56} \mathrm{CD} 19^{+} \mathrm{CD} 24^{\mathrm{hi}} \mathrm{CD} 38^{\text {hi }} \mathrm{B}$ cells have been reported to suppress $\mathrm{CD} 4^{+} \mathrm{T}$-cell proliferation and cytokine production; $\mathrm{T}_{\mathrm{h}} 1$ and $\mathrm{T}_{\mathrm{h}} 17$ differentiation; and HIV-1specific $\mathrm{CD}^{+}{ }^{+}$-cell responses, as well as convert naive $\mathrm{CD} 4^{+}$ $\mathrm{T}$ cells into Foxp $3^{+}$Tregs and IL-10-producing Tregs. ${ }^{25,56,61,62}$ The inhibitory activity of $\mathrm{CD} 19^{+} \mathrm{CD} 24^{\mathrm{hi}} \mathrm{CD} 38^{\text {hi }}$ Bregs was found to be dependent on IL-10 production, cell contact mediated by CD80-CD86 and, perhaps, PD-L1 expression. ${ }^{25,61,62}$ In contrast to the studies described above, IL- $10^{+} \mathrm{B}$ cells have been shown to fall within both the $\mathrm{CD} 27^{+}$ memory B cell and $\mathrm{CD} 19^{+} \mathrm{CD} 24^{\text {hi }} \mathrm{CD} 38^{\text {hi }}$ transitional B-cell pools, which suppress $\mathrm{CD} 4^{+}$T-cell proliferation and effector function. ${ }^{27,63}$ Furthermore, the presence of IL-10-producing B cells has also been identified within the naive CD27- B-cell population. ${ }^{64}$ More recently, Sarvaria et al. reported the presence of IL-10-producing Bregs in cord blood-derived naive and transitional B-cell compartments; they were reported to confer protection against chronic graft versus host disease by suppressing T-cell proliferation as well as effector function through IL-10 production and cell-to-cell contact involving CTLA- $4 .{ }^{65}$

Other phenotypes that have been described for human Breg subsets include $\mathrm{CD} 19^{+} \mathrm{CD} 24^{\text {hi }} \mathrm{CD} 27^{\text {int }} \mathrm{IL}-10^{+}$plasmablast regulatory B cells, which suppress autoimmune inflammation. ${ }^{43}$ In accordance with these findings, a recent study reported the presence of IL-10-producing B cells within both the CD24 ${ }^{\text {hi }}$ $\mathrm{CD} 27^{+}$and $\mathrm{CD} 27^{\text {high }} \mathrm{CD} 38^{\text {high }}$ plasmablast B-cell compartments, which are important in the regulation of human cGVHD. ${ }^{58}$ Furthermore, IgG4-expressing human inducible $\mathrm{CD} 25^{\mathrm{hi}} \mathrm{CD} 71^{\text {hi }} \mathrm{CD} 73^{\mathrm{lo}} \mathrm{IL}-10$-secreting B regulatory 1 cells have been found to potently suppress antigen-specific CD4+ T-cell proliferation, underlining a novel role for Bregs in allergen tolerance ${ }^{60}$ In addition, $\mathrm{CD} 39^{+} \mathrm{CD} 73^{+}$adenosine-producing 
Table 3 Phenotypic characteristics of Human regulatory B-cell subsets

\begin{tabular}{|c|c|c|c|}
\hline Breg Type & Phenotype & Key feature & $\begin{array}{l}\text { Ascribed } \\
\text { function }\end{array}$ \\
\hline B10 & CD24hicD27+ & $\begin{array}{l}\text { Found in human blood, produce IL-10, and suppress effector CD4+ T cells and monocyte } \\
\text { function }\end{array}$ & $23,26,55$ \\
\hline $\begin{array}{l}\text { Transitional B } \\
\text { cells }\end{array}$ & CD19+CD24 ${ }^{\text {hi }} C D 38^{\text {hi }}$ & $\begin{array}{l}\text { Produce IL-10, found in blood and at site of inflammation, induce Treg cells, suppress Th1 and } \\
\text { Th17 cells, suppress virus specific CD8+ T-cell responses }\end{array}$ & $25,27,56,57$ \\
\hline Memory B cells & CD19+CD27+lgM+ & $\begin{array}{l}\text { Produce IL-10 and found in human blood. Suppress CD4+ T-cell proliferation and effector } \\
\text { function }\end{array}$ & 27 \\
\hline Plasmablast & $\begin{array}{l}\text { CD19+CD38 }{ }^{\text {hi }} C D 24^{\text {hi }} \\
\text { CD2 } 7^{\text {int }}\end{array}$ & Produce IL-10, found in human blood and suppress DCs and effector CD4+ T cells & 43,58 \\
\hline GrB $+B$ cells & $\begin{array}{l}\text { CD19+CD38+CD1 } \mathrm{d}^{\mathrm{hi}} \\
\operatorname{lgM}+\mathrm{CD} 147+\end{array}$ & IL-21 induced Granzyme B-expressing B cells suppressed T-cell proliferation & 59 \\
\hline Br1 cells & $\begin{array}{l}\text { CD19+CD25 } 5^{\text {hi }} \text { CD71 } \\
\text { CDi } \\
\text { hilo }\end{array}$ & Found in blood and produce IL-10 and IgG4 & 60 \\
\hline
\end{tabular}

Abbreviations: Br1, B regulatory 1; DC, dendritic cell; IgG4, immunoglobulin G4; NK, natural killer.

Bregs have also been shown to suppress effector T-cell activation and proliferation by utilizing adenosine and IL-10. ${ }^{66}$ IL-21-induced $\mathrm{CD} 19^{+} \mathrm{CD} 38^{+} \mathrm{CD} 1 \mathrm{~d}^{+} \mathrm{IgM}^{+} \mathrm{CD} 147^{+}$ granzyme $\mathrm{B}$-expressing $\mathrm{B}$ cells that modulate $\mathrm{T}$-cell responses have also been reported to play a significant role in solid tumors. ${ }^{59}$ Human $\mathrm{CD} 19^{+} \mathrm{CD} 25^{\text {high }}$ Bregs have also been noted to suppress $\mathrm{CD}^{+} \mathrm{T}$-cell proliferation and enhance CTLA-4 and Foxp3 expression in Tregs via secretion of IL-10 and TGF- $\beta .{ }^{67}$

Taken together, although human Bregs have not been as extensively characterized as murine Bregs, emerging evidence on the importance of human Bregs in homeostasis has been reported. However, some controversy over the overlapping Breg phenotypes highlights the need for more extensive characterization of both mouse and human Bregs to improve our current understanding of Breg biology. These discrepancies reported in the characterization of Breg surface markers may be due to the different strategies that have been used to identify Bregs (membrane markers in one case and IL-10 intracellular staining in the second case). Thus, it is currently unclear whether the regulatory activity of Bregs is a feature that is specific to B-cell subsets or whether all B cells can acquire suppressive function in response to environmental stimuli. Nevertheless, akin to murine studies, IL-10 production is largely, although not exclusively, regarded as a crucial indicator of human Bregs, and the suppressive activity of Bregs both in vivo and in vitro currently serves as a vital standard in the study of Bregs.

\section{B-CELL REGULATION IN THE IMMUNE SYSTEM}

Bregs have been reported to modulate immune responses through diverse mechanisms that target different immune cell types (Figure 1).

\section{Role of IL-10 in Breg function}

The suppressive effect of Bregs on the production of IL-17 and IFN- $\gamma$ by Th17 and Th1 cells, respectively, and on the differentiation of $\mathrm{T}$ cells into Th17 cells in an IL-10dependent fashion has been described. ${ }^{37,56}$ In addition, Bregs have been shown to suppress $\mathrm{CD} 4^{+} \mathrm{T}$-cell proliferation and pro-inflammatory cytokine production through IL-10 25,27 and induce $\mathrm{CD}^{+}{ }^{+}$T-cell death through the expression of FasL. ${ }^{68}$ In addition to regulating $\mathrm{CD}^{+}{ }^{-}$-cell function, both human transitional and MZ Breg subsets have been shown to suppress $\mathrm{CD}^{+}$T-cell responses in an IL-10-dependent fashion. ${ }^{39,57}$ Hence, the dynamic and diverse interactions between Bregs and $\mathrm{T}$ cells play a pivotal role in immune regulation. Moreover, studies have demonstrated that Bregs not only can suppress T-cell effector responses but also can generate conventional Treg cells and IL-10-producing $\mathrm{T}$ cells from effector $\mathrm{T}$ cells through the production of IL-10. ${ }^{37,56}$ Carter et al indicated that IL-10-producing B cells are in contact with $\mathrm{CD} 4^{+} \mathrm{CD} 25^{-} \mathrm{T}$ cells for a longer period of time than IL-10-deficient B cells, which allows IL-10 ${ }^{+} \mathrm{B}$ cells to convert effector $\mathrm{T}$ cells into IL-10producing suppressive $\mathrm{T}$ cells. ${ }^{40}$ In addition to modulating T-cell functions, Bregs have been reported to suppress monocyte proliferation and cytokine production, which are mediated by IL-10 production. ${ }^{26}$ Furthermore, Bregs can also induce dendritic cells to produce IL-4 and downregulate IL-12, thereby affecting the Th1/Th2 balance. ${ }^{69}$ IL-10 has been posited to have a role in this immunoregulatory process. ${ }^{69}$ Moreover, Bregs have also been shown to suppress IFN- $\gamma$ production by NK cells via the production of IL-10. ${ }^{15}$

\section{IL-10-independent roles of Bregs}

In addition to IL-10 production, other mechanisms of Breg function have also been reported. IL-35-producing Bregs have been implicated as key players in the negative regulation of T-cell immunity during autoimmune and infectious diseases. ${ }^{42}$ Furthermore, Bregs have also been noted to suppress $\mathrm{CD}^{+}$ $\mathrm{T}$-cell proliferation ${ }^{68}$ and cytokine secretion and ${ }^{70} \mathrm{CD} 8^{+} \mathrm{T}$-cell responses, ${ }^{71}$ as well as to enhance CTLA- 4 and Foxp3 expression in Tregs $^{67}$ via the secretion of TGF- $\beta$. IL-21-induced 


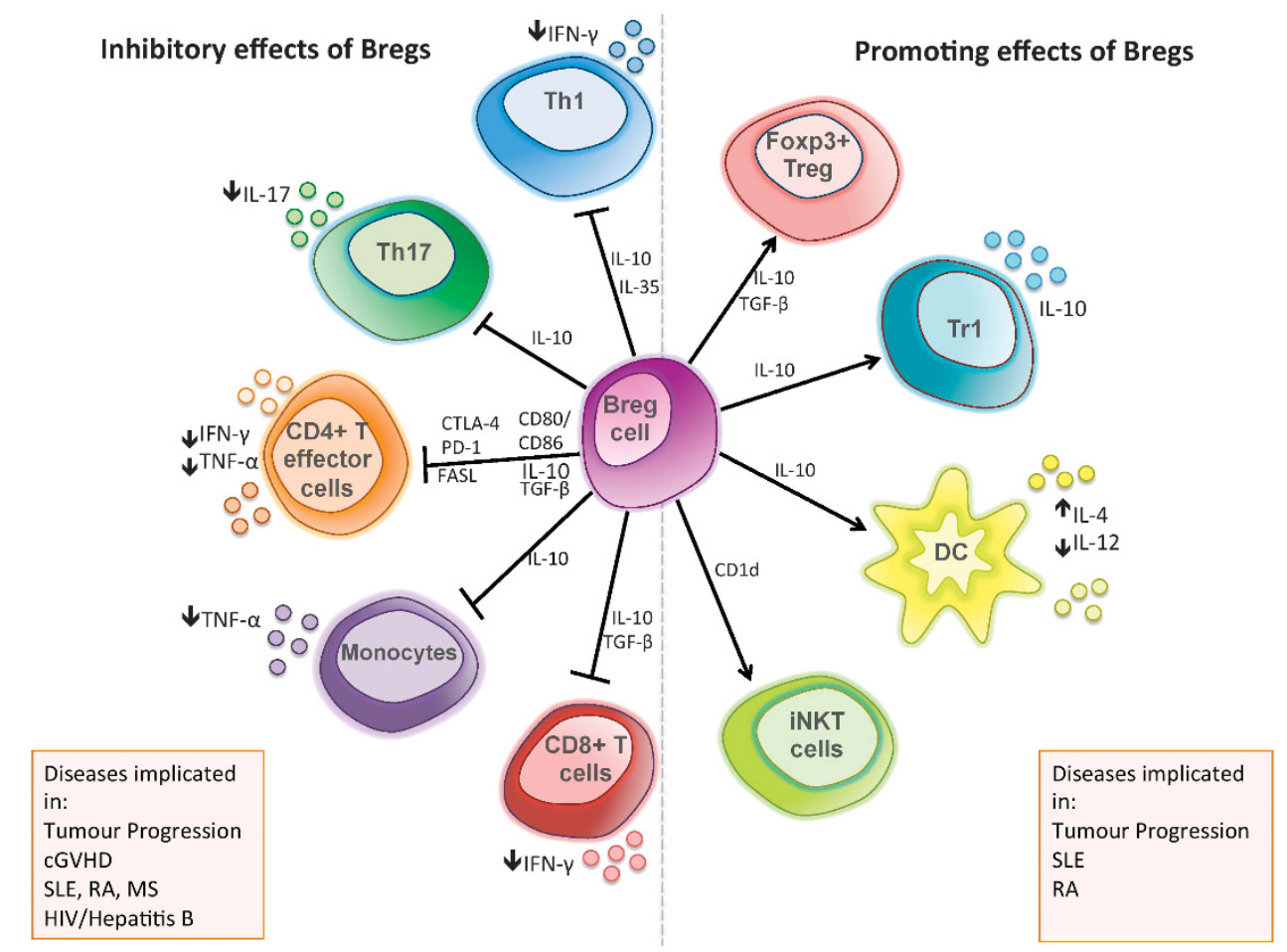

Figure 1 Functional mechanisms of B regulatory cells. Bregs can influence a variety of immune system components. The inhibitory effects of Bregs include suppression of the following: T-cell differentiation into Th1 and Th17 cells; pro-inflammatory cytokine production by CD4+ effector T cells; TNF- $\alpha$ production by monocytes; and cytotoxic CD8+ T-cell responses. Through the expression of FASL, Bregs can initiate apoptosis in effector $T$ cells. Bregs can also promote the differentiation of Foxp3+ $T$ cells and Tr1 cells, alter cytokine production by dendritic cells and support the maintenance of iNKT cells, which may possess a regulatory function. The functional mechanisms of Bregs are mediated through the release of soluble factors, such as IL-10, TGF- $\beta$, and IL-35, and through direct cell-cell contact via co-stimulatory molecules. Breg, regulatory B cells; cGVHD, chronic graft versus host disease; CTLA-4, cytotoxic T-lymphocyte protein 4; DC, dendritic cell; HIV, human immunodeficiency virus; IFN- $\gamma$, interferon $\gamma$; iNKT, invariant natural killer T-cell; MS, multiple sclerosis; RA, rheumatoid arthritis; SLE, systemic lupus erythematosus; TGF- $\beta$, transforming growth factor $\beta$; TH1, type 1 T helper cell; TH17, type $17 \mathrm{~T}$ helper cell; TNF- $\alpha$, tumor necrosis factor alpha; Tr1, type 1 regulatory $\mathrm{T}$ cell; Treg, regulatory $\mathrm{T}$ cell.

granzyme B-expressing Bregs have also been shown to modulate T-cell responses. ${ }^{59,72}$ In addition, the interaction between CTLA-4 and CD80/CD86 co-receptors has been proposed as a suppressive mechanism of Breg subsets. ${ }^{65}$ Further to these observations, Bregs have also been implicated in the maintenance of iNKT homeostasis. CD1d-mediated lipid antigen presentation by the human transitional Breg subset has been shown to activate and expand the iNKT pool, thus indicating a crucial role for Bregs in iNKT homeostasis. ${ }^{73}$

The diverse suppressive mechanisms of Breg function suggest that Bregs play a multifaceted role in immune regulation. Furthermore, although IL-10 has been implicated as the predominant effector of B-cell immunoregulatory activity in mice and humans, IL-10-independent suppressive mechanisms have also been reported. One possible explanation for this may be the different markers that have been used to define Bregs in various studies. Many surface markers that are used to characterize and isolate Breg subsets are either up- or downregulated during immune activation, which has led to a number of discrepancies in the definition of Breg subsets depending on the experimental conditions. Therefore, the mechanisms of Breg action may be varied and are still controversial. Hence, standardization of markers or the identification of a Breg cell-specific transcription factor, similar to Foxp3 for Treg cells, with which to characterize Bregs remains a challenge for future research. For these reasons, the suppressive activity of Bregs, via both direct and indirect mechanisms, currently serves as the gold standard for identifying Breg populations in various disease models. However, there are limited data on their role in the setting of cancer.

\section{B CELLS IN CANCER}

Although extensive research during the past decade has largely focused on the role of $\mathrm{T}$ cells in the field of immuno-oncology, a new wave of research has provided new insight into the potential association of B cells in carcinogenesis and tumor progression. B cells have been reported to play both positive and negative roles in tumor immunity.

\section{Negative regulation of cancer by murine $B$ cells}

Previous studies have suggested that murine B cells can promote anti-tumor immunity by facilitating T-cell-mediated immune responses that inhibit tumor development, and these 
responses are impaired in B-cell-depleted mice with B16 melanoma tumors. ${ }^{19}$ The indication that B cells augment T-cell immunity was reinforced when an increased tumor burden was observed in the lungs of melanoma-bearing mice following anti-CD20 antibody-mediated depletion of $\mathrm{CD} 20^{+} \mathrm{B}$ cells. CD20-depleted mice exhibited suppressed anti-tumor $\mathrm{T}$-cell responses, suggesting that $\mathrm{B}$ cell and $\mathrm{T}$-cell interactions are required to promote T-cell anti-tumor immunity. ${ }^{74} \mathrm{~A}$ further role for B cells in impairing tumor development was suggested by the observation that activated B cells were highly cytotoxic toward tumor cells, which was mediated by IgG2b. ${ }^{20}$ In addition, the presence of pulmonary host $\mathrm{B}$ cells was noted to promote IFN- $\gamma$ production and facilitate the killing of tumor cells by NK cells, suggesting a protective role for effector B cells against tumors. ${ }^{75}$ Taken together, these studies suggest a role for B cells in preventing tumor development. However, the findings from tumor experimental models may have limited application in the clinical setting as they involve preventing tumor development rather than the treatment of established tumors.

\section{Positive regulation of cancer by murine $B$ cells}

The first indication that $\mathrm{B}$ cells could be tumor promoting came from studies that were conducted almost 60 years ago. In these early works, the adoptive transfer of tumor-specific antibodies amplified the growth of transplanted tumor cells and chemically induced tumors, whereas the absence of B cells impaired tumor development. ${ }^{76-78}$ Subsequently, Coussens and colleagues showed that the presence of $\mathrm{B}$ cells in a murine model of squamous carcinogenesis reduced the infiltration of immune cells and fostered the progression of skin carcinoma. Despite low B-cell infiltration in the carcinoma lesions, antibodies secreted by B cells formed immune complexes that bound to Fc-gamma-activating receptors at neoplastic lesions at the tumor site. Consequently, myeloid cells including macrophages were recruited and primed to secrete immunoregulatory cytokines, supporting a subsidiary role for B cells in promoting inflammatory cascades during carcinogenesis. ${ }^{17,79}$ These observations suggest a role for B-cell-derived antibodies in tumor progression. Furthermore, in addition to antibody production, B-cell-derived lymphotoxin $\alpha / \beta$ has also been implicated in promoting tumor growth in castration-resistant prostate cancer in mice. ${ }^{80}$ After castration, secretion of lymphotoxin $\alpha / \beta$ by infiltrating B cells within the regressing tumor activated the inhibitor of NFkB a-kinase and STAT3, thus promoting androgen-independent tumor growth, which promoted relapse. ${ }^{80}$ Moreover, tumor-associated B cells that contain activated STAT3 have also been shown to promote angiogenesis, whereas B cells without STAT3 activation have the opposite effect in B16 melanoma and Lewis Lung Carcinoma mouse models. ${ }^{81}$ Hence, inhibition of STAT3 signaling may be a potential therapeutic target for the reduction of tumor growth.

In accordance with these findings, reduced tumor burden following anti-IgM antibody-mediated B-cell depletion in tumor-bearing mice also strengthened the role of $\mathrm{B}$ cells in positively regulating tumor progression. ${ }^{82}$ More recently, crosstalk between $\mathrm{B}$ and $\mathrm{T}$ lymphocytes has also been postulated to have a role in cancer progression. An increased T-cell immune response against adenocarcinoma tumor cells was observed in B-cell-deficient mice, whereas the presence of B cells has been postulated to inhibit cytotoxic T-lymphocyte-mediated tumor immunity. ${ }^{14}$ In addition, anti-CD20-mediated B-cell depletion was reported to augment $\mathrm{T}$-cell responses through increased $\mathrm{T}$-cell priming, whereas the presence of $\mathrm{B}$ cells correlated with suppressed anti-tumor immunity and a limited repertoire of $\mathrm{T}$ helper cells, ${ }^{14,83}$ suggesting that $\mathrm{B}$ cells may inhibit $\mathrm{T}$ cell cytokine secretion and consequently support tumor growth. Thus, given the role of $\mathrm{B}$ cells in the positive regulation of tumor progression and carcinogenesis, findings from these murine studies suggest that some cancer patients may benefit from B-cell inactivation while others may benefit from B-cell depletion. However, despite the presence of naturally occurring antibodies that are expected to kill tumor cells by complement activation, thereby causing antibody-mediated cellular cytotoxicity or initiating apoptosis, tumors can progress. One possible explanation for this may be that antibodies target autoantigens that are expressed on the surface of tumor cells, and as a result of tolerance mechanisms, high-affinity antibodies cannot be made in sufficient titers to mediate an effective antitumor response. However, vaccines that increase the endogenous production of these antibodies may possess therapeutic potential. For example, vaccination with a recombinant adenovirus expressing a truncated HER-2/neu antigen has been reported to produce sufficient amounts of antibodies to target HER-2/neu and eradicate breast cancer in a murine model. ${ }^{84}$

\section{Negative regulation of cancer by human $B$ cells}

Findings that human $\mathrm{B}$ cells negatively modulate tumor growth were noted when the presence of $\mathrm{CD} 20^{+} \mathrm{B}$-cell tumorinfiltrating lymphocytes in ovarian cancer, non-small lung carcinoma and cervical cancer correlated with improved survival and lower relapse rates. ${ }^{21,85,86}$ Findings from these studies showed that tumor-infiltrating B cells correlate with favorable outcomes. The potential mechanisms underlying B-cell anti-tumor immunity may involve the secretion of effector cytokines, such as IFN- $\gamma$, by B cells, which could polarize T cells towards a Th1 or Th2 response or promote $\mathrm{T}$-cell responses through their role as antigen-presenting cells. Further study on how B cells negatively regulate cancer could have important implications for developing effective anticancer therapies. Another example of the protective effect of $B$ cells in cancer is CpG-activated B cells that are capable of killing tumor cells through TRAIL/Apo-2L-dependent mechanisms, thus suggesting a novel role for B-cell-mediated direct cytotoxicity in cancer. ${ }^{87}$ Further support for the cytotoxic potential of B cells was reported in B-chronic lymphocytic leukemia, where IL-21 and CpG-treated leukemic cells produced elevated levels of granzyme B and induced apoptosis in bystander B-chronic lymphocytic leukemia cells. ${ }^{72}$ The results from this study shed 
light on new avenues of inducing the cytotoxic potential of $B$ cells to treat B-cell malignancies.

\section{Positive regulation of cancer by human B cells}

Human B cells also have been shown to foster tumor progression. Akin to murine studies, the presence of $\mathrm{B}$ cells with activated STAT3 in human tumor tissues was also found to correlate with the severity of tumor angiogenesis, thereby identifying B cells with STAT3 activity as mediators of tumor progression and potential targets for cancer therapy. ${ }^{81}$ Furthermore, the infiltration of $\mathrm{CD} 19^{+} \mathrm{B}$ cells in patients with metastatic ovarian carcinoma is associated with poor disease outcome. $^{88}$ In addition, an increase in $\mathrm{CD} 20^{+}$and $\mathrm{CD} 138^{+}$ B-cell infiltration in patients with epithelial ovarian cancer was associated with poorer prognosis. ${ }^{89}$ In contrast to this observation, increased $\mathrm{CD} 20^{+}$B-cell infiltration has also been correlated with a better prognosis, possibly because the tumorinfiltrating $\mathrm{B}$ cells may act as antigen-presenting cells to mediate cytolytic T-cell responses against tumors. ${ }^{21}$ Thus, there have been conflicting reports regarding the role of tumorinfiltrating CD $20^{+} \mathrm{B}$ cells. It is possible that $\mathrm{CD} 20^{+} \mathrm{B}$ cells may function as antigen-presenting cells to aid in anti-tumor immunity, and $\mathrm{CD} 138^{+}$plasma cells may secrete antibodies or function as Bregs and promote tumor growth. Better characterization of these B-cell subpopulations may provide further insight into these conflicting results. Furthermore, reduced tumor burden following partial B-cell deletion with rituximab was observed in $50 \%$ of patients with advanced colorectal cancer, which supported a role for B cells in positively regulating tumor progression. ${ }^{82}$ Moreover, better prognosis in $40 \%$ of breast carcinoma patients was associated with the presence of tumor-specific $\mathrm{T}$-cell responses in the bone marrow, whereas in approximately $50 \%$ of patients, the presence of tumor-specific natural antibodies correlated with the absence of bone marrow tumor-specific $\mathrm{T}$ cells and advanced tumor stage. ${ }^{90}$ The results from these clinical observations suggest that B cells and their underlying mechanisms may have regulatory properties that facilitate tumor progression.

\section{REGULATORY B-CELL SUBSETS IN CANCER}

It has been extensively acknowledged that numerous discrete immunogenic cancers are driven by a chronic inflammatory milieu, which is generally associated with tumor progression. ${ }^{1,2}$ Thus, given the ability of $\mathrm{B}$ cells to harness $\mathrm{T}$-cell responses and promote tumor growth, a role for Bregs has recently been implicated in cancer.

\section{Mouse Breg subsets in cancer}

Schioppa and colleagues identified a population of splenic IL-10-producing $\mathrm{CD} 19^{+} \mathrm{CD} 21^{+}$Bregs implicated in the suppression of $\mathrm{CD}^{+} \mathrm{IFN}-\gamma^{+} \mathrm{T}$ cells, which promoted papilloma development and cancer growth in a model of induced skin carcinogenesis. ${ }^{18}$ They also reported that TNF- $\alpha$ mediated the suppressive capacity of IL-10-producing Bregs in limiting antitumor immunity and promoting tumor development. ${ }^{18}$
Similarly, splenic cells from B-cell-deficient mice exhibited increased IFN- $\gamma$ production by CD8 $+\mathrm{T}$ cells and NK cells following stimulation and co-culture with irradiated tumor cells in vitro compared with wild-type cells. ${ }^{15}$ IFN- $\gamma$ production is inversely correlated with IL-10 production in B cells and provides additional insights into the mechanisms of Bregs in increasing tumor progression. ${ }^{15}$ The findings from this study suggest that the specific inhibition of Bregs warrants further research.

In addition, the role of IL-10-producing Bregs was also reported in chronic lymphocytic leukemia (CLL), where CLL cells were reported to resemble Bregs in terms of their phenotype $\left(\mathrm{CD} 1 \mathrm{~d}^{\text {high }} \mathrm{CD} 5^{+}\right)$and ability to secrete IL-10, which indicated that Bregs might promote malignant expansion. ${ }^{91}$ Moreover, the presence of IL-10-producing Bregs was shown to inhibit the therapeutic efficacy of the humanized anti-CD20 antibody rituximab, which has proven to be effective in the treatment of non-Hodgkin lymphoma and CLL through B-cell depletion. ${ }^{91}$ Since Bregs express low levels of CD20, CD20depletion mostly enriched tumor-induced Bregs and subsequently enhanced metastasis in a murine model of breast cancer. ${ }^{91,92}$ In addition, IL-10-producing $\mathrm{CD} 1 \mathrm{~d}^{\text {high }} \mathrm{CD} 5^{+}$Bregs were reported to increase tumor burden by suppressing the phagocytic capacity of macrophages/monocytes both in vivo and in vitro. ${ }^{91,93}$ These findings suggest a role for IL-10producing Bregs in suppressing anti-tumor immunity, which is required for the clearance of anti-CD20-bound tumor cells and augmenting the development of lymphoma resistance to antiCD20 therapy. However, this study did not evaluate the efficiency of Breg depletion following anti-CD20 antibody treatment; it would be interesting to study the presence of anti-CD20-antibody-resistant Bregs. These findings were, however, reconciled by reports on the presence of an enriched population of CD20 low $4-1 \mathrm{BBL}{ }^{\text {low }} \mathrm{B}$ cells, which exhibited increased T-cell suppressive effects ex vivo compared to control mice following anti-CD20 therapy in 4T1 tumor-bearing mice. ${ }^{92}$ However, treatment with $\mathrm{CPG}-\mathrm{ODN}$ upregulated CD20 and 4-1BBL expression, inhibited B-cell suppressive function and reversed the enhanced metastasis induced by anti-CD20 therapy. ${ }^{92}$ The relative enrichment of CD20 ${ }^{\text {low }} 4$ $1 \mathrm{BBL}^{\text {low }}$ Bregs may be a plausible explanation for the limited success of rituximab in patients with melanoma and renal cell carcinoma, ${ }^{94}$ and strategies using CPG-ODN may be useful in reversing the induction of Breg suppression.

In addition to these findings, the presence of tumor-induced Bregs has also been reported. IL-21-induced granzyme B-expressing Bregs have been implicated in various types of tumors, such as ovarian, cervical, breast, prostate and colorectal carcinomas, where they have been noted to modulate cellular adaptive immune responses by facilitating tumor escape mechanisms against antitumor immune attack. ${ }^{59}$ In addition, a preferential accumulation of the T2-MZP Breg subset in the tumor-draining popliteal lymph nodes of tumor-bearing mice was reported to accelerate tumor growth. ${ }^{55}$ However, the mechanisms by which T2-MZP Bregs promote tumor growth require further study. Similarly, the presence of tumor- 
infiltrating B cells with increased expression of PD-L1, LAP/ TGF- $\beta$, CD80 and CD86 compared to splenic B cells in vivo suppressed $\mathrm{CD}^{+} \mathrm{T}$ cell, $\mathrm{CD} 8^{+} \mathrm{T}$ cell and $\mathrm{NK}$ cell proliferation. ${ }^{95}$ Monoclonal antibodies targeting TGF- $\beta$ or PD-L1 dramatically suppressed tumor growth in wild-type mice, suggesting that targeting this unique Breg subset could be a potential therapeutic target. ${ }^{95}$ Mechanisms underlying the recruitment and induction of Breg activity are being studied.

Furthermore, Bregs have also been shown to promote tumor growth by recruiting Tregs that suppress T-cell-mediated cytotoxic activity against EMT-6 tumor cells and reduce tumor infiltration by $\mathrm{CD}^{+} \mathrm{T}$ cells and $\mathrm{CD} 49^{+} \mathrm{NK}$ cells within the tumor microenvironment. ${ }^{96}$ Although the suppressive mechanisms whereby B cells mediate antineoplastic effects were found to be independent of IL-10 and require further study, B cell-T cell crosstalk is likely involved. In accordance with these findings, Olkhanud et al identified a unique population of tumor-evoked $\mathrm{CD} 19^{+} \mathrm{B} 220^{+} \mathrm{CD} 25^{+} \mathrm{B}$ cells (termed tBregs by the authors) that facilitated the progression of tumor metastasis in the lungs of a murine breast cancer model, $4 \mathrm{~T} 1 .{ }^{97}$ The $4 \mathrm{~T} 1$ tumor cells directly evoked the generation of tBregs by producing uncharacterized soluble factors, which requires further study. The induced tBregs suppressed T-cell proliferation and induced the conversion of naive $\mathrm{CD}^{+} \mathrm{T}$ cells into FoxP3 $^{+}$Tregs, which was mediated by TGF- $\beta$ secretion and cell-to-cell contact between $\mathrm{T}$ and $\mathrm{B}$ cells. ${ }^{97}$ The transformed Tregs were then reported to suppress the antitumor defenses of NK cells, thereby favoring tumor metastasis. ${ }^{97}$ It is noteworthy that the inhibitory role of Bregs was dependent on TGF- $\beta$, and the authors did not describe a role for IL-10 in this study, similar to a previous observation in a similar setting. ${ }^{96,97}$ One possible explanation for this may be the different markers that were used to characterize Bregs in this setting; hence, the standardization of markers that are used to characterize Bregs remains a challenge for future research. Furthermore, although the authors showed that the majority of $\mathrm{CD} 19^{+}$tBregs were also $\mathrm{B} 220^{+}$, the anti-B220 antibody-mediated depletion of $\mathrm{B} 220^{+}$ cells was sufficient to reduce lung metastases in mice, but it was not accompanied by a decrease in $\mathrm{CD}_{1} 9^{+} \mathrm{B}$ cells. ${ }^{97}$ Thus, adoptive transfer of $\mathrm{CD}_{1} 9^{+}$tBregs would help to further understand their role in mammary carcinoma. Overall, the above study supports the role of tBregs in facilitating the establishment of lung metastasis through the suppression of T-cell-mediated anti-tumor immunity and the induction of regulatory cells. Another study of the $4 \mathrm{~T} 1$ breast cancer model also supported the ability of Bregs to induce Tregs. ${ }^{97}$ Non-metastatic cancer cells produce metabolites of the 5-lipoxygenase (5-LO) pathway, which induce the development of tBregs through peroxisome proliferator-activated receptor $\alpha$ (PPAR $\alpha)$, which then suppress proliferation and induce Treg conversion. ${ }^{98}$ These findings further reinforced a role for BregTreg crosstalk in fostering tumor progression within the tumor microenvironment. Collectively, murine Bregs have been shown to suppress anti-tumor immunity and promote tumor growth, underscoring the importance of targeting Bregs for cancer therapy.

\section{Human Breg subsets in cancer}

Aside from the role of mouse Bregs in cancer, a new wave of evidence has also implicated a role for human Bregs in cancer progression. Similar to the murine studies, analysis of IL-10producing $\mathrm{CD} 1 \mathrm{~d}^{\text {high }} \mathrm{CD}^{+} \mathrm{B}$ cells isolated from CLL patients treated with rituximab revealed that anti-CD20-mediated B-cell depletion mostly enriched a Breg pool. The enriched Bregs were postulated to suppress the anti-tumor immunity required for the clearance of anti-CD20-bound tumor cells, causing patients to develop lymphoma resistance towards anti-CD20 therapy and/or eventually relapse as a result of enhanced cancer progression. $^{91,92}$ In addition, higher frequencies of IL-10producing $\mathrm{CD} 19^{+} \mathrm{CD}^{+}$Bregs have also been correlated with the increased clinical progression of esophageal cancer. ${ }^{99}$ Moreover, $\mathrm{CD}^{+}$Bregs have been proposed to promote cancer through the suppression of anti-tumor responses via activated STAT3, a transcription factor that contributes to IL-10 secretion. ${ }^{100}$

Furthermore, upregulation of IL-10-producing Bregs was reported to correlate with increased frequencies of $\mathrm{CD} 4^{+} \mathrm{CD} 25^{+}$ CD127 ${ }^{\text {low }}$ Tregs and CD14 ${ }^{+} \mathrm{HLA}^{-} \mathrm{DR}^{\text {low }}$ myeloid-derived suppressor cells as well as increased progression of carcinoma and reduced patient survival. ${ }^{101,102}$ IL-10 secretion by Bregs was reported to induce the conversion of $\mathrm{CD}^{+} \mathrm{T}$ cells into Tregs and could be one of the mechanisms that modulate cancer progression. ${ }^{102}$ In accordance with these findings, patients with ovarian cancer also express elevated frequencies of IL-10producing naive or $\mathrm{IgM}^{+}$memory B cells that correlate with higher frequencies of $\mathrm{FoxP}^{+} \mathrm{CD}^{+}$Tregs and exhibit suppressed IFN- $\gamma$ production by $\mathrm{CD} 8^{+} \mathrm{T}$ cells, which is mediated through both IL-10 secretion and cell-to-cell contact via CD80/ CD86 expression. ${ }^{103}$ The positive correlation between high Breg and Treg frequencies has also been reported in patients with gastric cancer, where IL-10-producing $\mathrm{CD}^{+}{ }^{+}$ $\mathrm{CD} 24^{\text {hi }} \mathrm{CD} 38^{\text {hi }}$ Bregs were found to suppress $\mathrm{CD} 4^{+} \mathrm{T}$-cell cytokine secretion and induce the differentiation of Tregs, which was mediated by TGF- $\beta 1 .^{70}$ More recently, a bone marrow-derived $\mathrm{CD} 19^{+} \mathrm{CD} 24^{\text {high }} \mathrm{CD} 38^{\text {high }}$ Breg population was also reported to abrogate NK cell-mediated ADCC against multiple myeloma cells in multiple myeloma patients though the production of IL-10. ${ }^{104}$ Collectively, these findings implicate the role of Bregs in inhibiting T-cell- and NK cellmediated immunity and generating Tregs to promote cancer progression, which parallels studies of murine Bregs in cancer. The interaction of human Bregs with Tregs and their underlying mechanisms of aiding tumor immune escape warrant further investigation.

In addition to the conventional human Breg phenotypes described above, a unique subset of $\mathrm{PD}-\mathrm{1}^{\mathrm{hi}}$-expressing $\mathrm{CD} 5{ }^{\text {hi }} \mathrm{CD} 24^{-/+} \mathrm{CD} 27^{\mathrm{hi} /+} \mathrm{CD} 38^{\mathrm{dim}}$ Bregs induced by human hepatocellular carcinoma (HCC) environmental factors, such as TLR4-mediated BCL6 upregulation, has also been reported to suppress T-cell anti-tumor immunity and foster tumor progression through IL-10 secretion and PD-1 expression. ${ }^{105}$ The results from this study shed light on new avenues to inhibit Breg function in cancer immunotherapy, such as targeting the 
PD-1/PDL-1 axis. Moreover, an increased percentage of CD19 ${ }^{+}$ $\mathrm{CD} 24^{+} \mathrm{CD} 38^{+}$Bregs in HCC patients has also been found to correlate with advanced tumor staging compared to patients with early stages of HCC and healthy controls. ${ }^{106} \mathrm{CD} 19^{+}$ $\mathrm{CD} 24^{+} \mathrm{CD} 38^{+}$Bregs in $\mathrm{HCC}$ patients have been shown to promote HCC cell growth through direct interactions with hepatic cancer cells via the CD40/CD154 signaling pathway, thus supporting a role for Bregs in cancer progression. ${ }^{107}$ Furthermore, glioma cell-derived placental growth factor has been shown to promote the proliferation of intratumoral B cells by inducing their differentiation from naive $\mathrm{B}$ cells into TGF- $\beta^{+}$Bregs that suppress $\mathrm{CD} 8^{+}$responses. ${ }^{71}$ Thus, placental growth factor may play a key role in mediating the induction of regulatory phenotypes in $\mathrm{B}$ cells.

The findings from the studies of human Bregs in cancer underscore the ability of different Breg subsets to mediate immunosuppression in support of tumor growth through the suppression of effector T cells and NK cells and the expansion of suppressive Tregs and myeloid-derived suppressor cells to limit anti-tumor immunity. It is unclear whether Bregs actively promote tumor growth or if an increase in the Breg population merely reflects an immune response against the tumor. However, in order to identify whether Bregs enhance tumor progression, strategies to deplete or inhibit Bregs via cancer immunotherapy are required. Although strategies to deplete B cells may potentially improve the results of cancer immunotherapy by eradicating Bregs and promoting anti-tumor immunity, interestingly, not all strategies of B-cell depletion have achieved equal success. This has been illustrated through several studies that have reported a limited efficiency or failure of $\alpha$-CD20 mAb therapy in several tumor models. A possible explanation for this could be the presence of anti-CD20antibody-resistant B cells or Breg subsets that escape anti-CD20 therapy. Therefore, to reconcile findings from previous studies with the current view that immunosuppressed individuals present an increased incidence of certain types of cancer, ${ }^{17}$ further studies investigating the effects of different strategies of targeting B-cell subsets and different timing of B-cell depletion on tumor progression are required. Furthermore, B-celldepleting antibodies cannot distinguish between effector and regulatory B-cell subsets. Although several markers have been used to characterize the majority of IL-10-producing Bregs, they are not sufficiently specific to Bregs to be used in cellular therapy. Thus, further meticulous characterization and study of Breg subsets in the tumor microenvironment will be required to identify Breg-specific targets that could be used to selectively deplete key Breg populations and to fine-tune anticancer immunotherapies.

\section{Development of Bregs in the tumor microenvironment}

To date, relatively little is known about the development of Bregs in the tumor microenvironment. Previous studies have shown that tumor cells may attract naive B cells into the tumor microenvironment through chemoattractants and promote their differentiation into Breg cells through secreted factors and cell contact-dependent mechanisms. An expanded subset of $\mathrm{CD} 25^{+} \mathrm{CD} 19^{+} \mathrm{CD} 220^{+}$tBregs that facilitated tumor metastasis was shown to be induced by soluble factors in a 4T1 murine cancer model. ${ }^{97}$ 4T1 murine cancer cells have been reported to induce the differentiation of tBregs by producing metabolites of the 5-LO pathway, such as leukotriene $\mathrm{B}_{4}$, which activates the PPAR $\alpha$ receptor expressed by B cells. ${ }^{98}$ Inhibitors of the 5-LO pathway were found to reduce the generation of tBregs, highlighting the crucial role of PPAR $\alpha$ activation in the differentiation and suppressive activity of tBregs. ${ }^{98}$ Other factors have also been implicated in the differentiation of $\mathrm{B}$ cells into Bregs within the tumor microenvironment. Glioma cell-derived placental growth factor has been shown to induce the regulatory phenotype and proliferation of intratumoral $\mathrm{B}$ cells by promoting their differentiation from tumor-infiltrating B cells into TGF- $\beta^{+}$Bregs. ${ }^{71}$ Moreover, TNF- $\alpha$ secreted by tumor cells and IL-21 secreted by $\mathrm{T}$ cells have also been recognized as Breg-induced factors in the tumor microenvironment. ${ }^{18,59}$ In addition to soluble factors, cell contact via CD40L, which is expressed on tumor cells, was reported to induce $\mathrm{CD} 19^{+} \mathrm{IL}-10^{+}$Bregs through the $\mathrm{CD} 40-$ CD40L pathway, ${ }^{102}$ which is consistent with previous findings where CD40L expression triggered the differentiation of Bregs. ${ }^{56}$ However, upon CD40 blockade, the induction of Bregs was not completely inhibited, suggesting that other factors are likely involved in Breg development. ${ }^{102}$ Furthermore, cell contact via the PD-1-PD-L1 axis has also been shown to increase tumor infiltration by Bregs. ${ }^{105}$

Collectively, the studies above suggest that one potential immune escape mechanism employed by tumor cells to generate an immunosuppressive environment that supports tumor growth could be by inducing Breg differentiation via cell-cell contact and soluble factors. Tumor cells may promote Breg differentiation either directly (by releasing soluble factors or through cell contact) or indirectly by recruiting other immune cells, such as IL-21-producing T cells, which in turn induce the generation of suppressive Bregs within the tumor microenvironment. However, further investigation into the exact mechanisms that underlie the conversion of normal $\mathrm{B}$ cells into tBregs and the origin and nature of the signals that induce Breg differentiation and suppressive activity in the tumor microenvironment will allow us to more accurately and effectively manipulate Breg-targeted therapy. Hence, study of the factors that could reshape and reset the immune system merits further investigation.

\section{FUTURE DIRECTIONS AND CHALLENGES}

The suppressive capacity of Bregs has attracted increasing attention in disease regulation as well as in attenuating immune responses and facilitating Treg differentiation in various immune-related pathologies, including cancer. However, much remains to be understood regarding the biology of Bregs in mice and humans.

Bregs have been reported to promote tumor progression by interacting with tumor cells, by suppressing anti-tumor responses to help tumor cells evade immune surveillance and by negatively affecting the effectiveness of immunotherapies 
involving tumor-targeted monoclonal antibodies. However, complete understanding of the nature of the cellular and/or soluble factors involved in promoting the induction of Bregs during cancer progression remains understudied. The current understanding is that as long as the cancer persists, it will induce tBregs, which will initiate a chain of suppressive events. However, further characterization of pro- vs. antitumor B-cell subsets should help to identify the exact role of Bregs and related factors in the tumor microenvironment. Furthermore, regulating the activity of these Breg-suppressive cells in the tumor microenvironment without compromising peripheral tolerance remains a significant challenge for cancer immunotherapy. For example, B-cell depletion using anti-CD20 antibodies and/or inhibitors of B-cell signaling pathways (for example, ibrutinib) in cases where B cells are considered to be the main drivers of disease pathology may need to be reconciled with strategies to selectively target Bregs to treat cancer. Moreover, recent accomplishments in reversing B-cellmediated immune suppression by using anti- PD-1 antibodies (also called checkpoint inhibitors), such as nivolumab or pidilizumab, in early Phase I/II trials to treat Hodgkin's and non-Hodgkin's lymphomas, have supported the therapeutic strategy of targeting Bregs.

Reports on B-cell depletion in cancer models have drawn the interest of a wide spectrum of immunologists and clinicians. However, it is essential to first understand the differentiation and function of these cells in more detail. Despite the extensive body of evidence suggesting a role for Bregs in cancer progression, controversy over the paucity of markers that can unequivocally identify Bregs, particularly in humans, remains a subject of debate and represents a significant challenge for Breg-based cancer therapies. The discrepancies reported in the phenotypic characterization of Bregs may stem from the different strategies used to identify and purify Breg subsets. At present, there is limited evidence supporting the hypothesis that Bregs belong to a unique lineage. New findings regarding the plasticity of lymphocytes support the idea that Bregs and B effector cells arise from the same progenitors, which are capable of being reprogrammed according to the immunological requirements of the inflammatory environment. Thus, it is currently undetermined whether the regulatory activity of Bregs is a feature that is specific to B-cell subsets or whether all $B$ cells can acquire suppressive functions in response to environmental stimuli. Although IL-10 production by Breg subsets is largely used as a marker for Breg identification, Bregs have been shown to mediate immune suppression through both IL-10-dependent and independent mechanisms. For this reason, the suppressive activity of Bregs both in vitro and in vivo currently serves as the gold standard in the study of Bregs. The question of whether all IL-10-producing B cells are suppressive irrespective of their phenotype, whether multiple Breg subsets exist and whether they are all equipollent has yet to be determined.

In conclusion, there have been many advances in the understanding of Breg cells and the mechanisms that control Breg cell differentiation. Taken together, the identification of a unique Breg signature and the complete understanding of the interactions between Bregs and other components of the immune system in the setting of cancer are necessary. Future research efforts should focus on investigating the utility of Bregs as a biomarker of clinical outcome in cancer and providing new avenues for Breg-targeting immunotherapies that augment the anti-tumor immune response against tumors and cancer progression.

\section{CONCLUSION}

In summary, the relationship between cancer escape and the immune system in regulating tumor progression has been well described in recent years. There is emerging evidence of the role of Bregs, a newly defined subpopulation of suppressor B cells, in regulating immunity to tumors and lymphoid malignancies. Although the role of human Bregs has not been explored as much as that of murine Bregs, there is convincing evidence for an anti-tumor Breg function in humans. As discussed above, Bregs in murine tumor models and cancer patients have been shown to promote tumor progression by attenuating anti-tumor immunity via the T-cell immune response suppression through the secretion of antiinflammatory mediators, such as IL-10, TGF- $\beta$ and IL-35, and by facilitating the generation of Tregs. However, despite a pivotal role for Bregs in promoting inflammation and carcinogenesis, there is a lack of consensus on a unique signature with which to unequivocally identify Bregs, thereby limiting their study. Thus, additional work is necessary to identify cell surface markers that are unique to Bregs in mice and humans and to define Bregs as a biomarker of clinical outcome in cancer. In addition, continued effort toward studying the probable impact of targeting Bregs for augmenting antitumor immunity in cancer treatment will pave the way for novel Breg-based immunotherapies.

\section{CONFLICT OF INTEREST}

The authors declare no conflict of interest.

\section{ACKNOWLEDGEMENTS}

This work was funded and supported by Anthony Nolan.

1 Grivennikov SI, Greten FR, Karin M. Immunity, inflammation, and cancer. Cell 2010; 140: 883-899.

2 Kim R, Emi M, Tanabe K. Cancer immunoediting from immune surveillance to immune escape. Immunology 2007; 121: 1-4.

3 Gunderson AJ, Coussens LM. B cells and their mediators as targets for therapy in solid tumors. Exp Cell Res 2013; 319: 1644-1649.

4 Naradikian MS, Scholz JL, Oropallo MA, Cancro MP. Understanding B Cell Biology. Drugs Targeting B-Cells in Autoimmune Diseases. Springer: Basal, 2014; 11-35.

5 Shen P, Fillatreau S. Antibody-independent functions of B cells: a focus on cytokines. Nat Rev Immunol 2015; 15: 441-451.

6 Allman D, Pillai S. Peripheral B cell subsets. Curr Opin Immunol 2008; 20: 149-157.

7 Carsetti R, Rosado MM, Wardmann H. Peripheral development of B cells in mouse and man. Immunol Rev 2004; 197: 179-191.

8 Kurosaki T. B-lymphocyte biology. Immunol Rev 2010; 237: 5-9. 
9 LeBien TW, Tedder TF. B lymphocytes: how they develop and function. Blood 2008; 112: 1570-1580.

10 Pieper K, Grimbacher B, Eibel H. B-cell biology and development. J Allergy Clin Immunol 2013; 131: 959-971.

11 Weill JC, Weller S, Reynaud CA. Human marginal zone B cells. Annu Rev Immunol 2009; 27: 267-285.

12 Garraud O, Borhis G, Badr G, Degrelle S, Pozzetto B, Cognasse F et al. Revisiting the B-cell compartment in mouse and humans: more than one B-cell subset exists in the marginal zone and beyond. BMC Immunol 2012; 13: 1 .

13 Oleinika K, Nibbs RJ, Graham GJ, Fraser AR. Suppression, subversion and escape: the role of regulatory T cells in cancer progression. Clin Exp Immunol 2013; 171: 36-45.

14 Qin Z, Richter G, Schüler T, Ibe S, Cao X, Blankenstein T. B cells inhibit induction of $\mathrm{T}$ cell-dependent tumor immunity. Nat Med 1998; 4: 627-630.

15 Inoue S, Leitner WW, Golding B, Scott D. Inhibitory effects of B cells on antitumor immunity. Cancer Res 2006; 66: 7741-7747.

16 Fremd C, Schuetz F, Sohn C, Beckhove P, Domschke C. B cellregulated immune responses in tumor models and cancer patients. Oncoimmunology 2013; 2: e25443.

17 De Visser KE, Korets LV, Coussens LM. De novo carcinogenesis promoted by chronic inflammation is B lymphocyte dependent. Cancer Cell 2005; 7: 411-423.

18 Schioppa T, Moore R, Thompson RG, Rosser EC, Kulbe H, Nedospasov S et al. B regulatory cells and the tumor-promoting actions of TNF- $\alpha$ during squamous carcinogenesis. Proc Natl Acad Sci USA 2011; 108: 10662-10667.

19 DiLillo DJ, Yanaba K, Tedder TF. B cells are required for optimal CD4 + and CD8+ T cell tumor immunity: therapeutic B cell depletion enhances B16 melanoma growth in mice. J Immunol 2010; 184: 4006-4016.

20 Li Q, Teitz-Tennenbaum S, Donald EJ, Li M, Chang AE. In vivo sensitized and in vitro activated $\mathrm{B}$ cells mediate tumor regression in cancer adoptive immunotherapy. J Immunol 2009; 183: 3195-3203.

21 Nielsen JS, Sahota RA, Milne K, Kost SE, Nesslinger NJ, Watson PH et al. CD20+ tumor-infiltrating lymphocytes have an atypical CD27 memory phenotype and together with $\mathrm{CD} 8+\mathrm{T}$ cells promote favorable prognosis in ovarian cancer. Clin Cancer Res 2012; 18: 3281-3292.

22 Mauri C, Gray D, Mushtaq N, Londei M. Prevention of arthritis by interleukin 10-producing B cells. J Exp Med 2003; 197: 489-501.

23 Yanaba K, Bouaziz JD, Haas KM, Poe JC, Fujimoto M, Tedder TF. A regulatory $B$ cell subset with a unique $\mathrm{CD} 1 \mathrm{dhi}$ CD5+ phenotype controls T cell-dependent inflammatory responses. Immunity 2008; 28: 639-650.

24 Blair PA, Chavez-Rueda KA, Evans JG, Shlomchik MJ, Eddaoudi A, Isenberg DA et al. Selective targeting of B cells with agonistic antiCD40 is an efficacious strategy for the generation of induced regulatory T2-like $\mathrm{B}$ cells and for the suppression of lupus in MRL/Ipr mice. J Immunol 2009; 182: 3492-3502.

25 Blair PA, Noreña LY, Flores-Borja F, Rawlings DJ, Isenberg DA, Ehrenstein MR et al. CD19+ CD24 hi CD38 hi B cells exhibit regulatory capacity in healthy individuals but are functionally impaired in systemic lupus erythematosus patients. Immunity 2010; 32: 129-140.

26 Iwata Y, Matsushita T, Horikawa M, DiLillo DJ, Yanaba K, Venturi GM et al. Characterization of a rare IL-10-competent B-cell subset in humans that parallels mouse regulatory B10 cells. Blood 2011; 117: 530-541.

27 Khoder A, Sarvaria A, Alsuliman A, Chew C, Sekine T, Cooper N et al. Regulatory $B$ cells are enriched within the IgM memory and transitional subsets in healthy donors but are deficient in chronic GVHD. Blood 2014; 124: 2034-2045.

28 Rosser EC, Mauri C. Regulatory B cells: origin, phenotype, and function. Immunity 2015; 42: 607-612.

29 DiLillo DJ, Matsushita T, Tedder TF. B10 cells and regulatory B cells balance immune responses during inflammation, autoimmunity, and cancer. Ann NY Acad Sci 2010; 1183: 38-57.

30 Khan AR, Hams E, Floudas A, Sparwasser T, Weaver CT, Fallon PG. PD-L1hi B cells are critical regulators of humoral immunity. Nat Commun 2015; 6: 5997.

31 Katz SI, Parker D, Turk JL. B-cell suppression of delayed hypersensitivity reactions. Nature 1974; 251: 550-551.
32 Neta R, Salvin SB. Specific suppression of delayed hypersensitivity: the possible presence of a suppressor $B$ cell in the regulation of delayed hypersensitivity. J Immunol 1974; 113: 1716-1725.

33 Shimamura T, Hashimoto K, Sasaki S. Feedback suppression of the immune response in vivo: I. Immune B cells induce antigen-specific suppressor T cells. Cell Immunol 1982; 68: 104-113.

34 Shimamura T, Habu S, Hashimoto K, Sasaki S. Feedback suppression of the immune response in vivo: III. Lyt-1+ B cells are suppressor-inducer cells. Cell Immunol 1984; 83: 221-224.

35 Mizoguchi A, Mizoguchi E, Takedatsu H, Blumberg RS, Bhan AK. Chronic intestinal inflammatory condition generates IL-10-producing regulatory B cell subset characterized by CD1d upregulation. Immunity 2002; 16: 219-230.

36 Fillatreau S, Sweenie CH, McGeachy MJ, Gray D, Anderton SM. B cells regulate autoimmunity by provision of IL-10. Nat Immunol 2002; 3: 944-950.

37 Carter NA, Rosser EC, Mauri C. Interleukin-10 produced by B cells is crucial for the suppression of Th17/Th1 responses, induction of $T$ regulatory type 1 cells and reduction of collagen-induced arthritis. Arthritis Res Ther 2012; 14: 1.

38 Brummel R, Lenert P. Activation of marginal zone B cells from lupus mice with type A (D) CpG-oligodeoxynucleotides. J Immunol 2005; 174: 2429-2434.

39 Bankoti R, Gupta K, Levchenko A, Stäger S. Marginal zone B cells regulate antigen-specific $T$ cell responses during infection. J Immunol 2012; 188: 3961-3971.

40 Carter NA, Vasconcellos R, Rosser EC, Tulone C, Muñoz-Suano A, Kamanaka $\mathrm{M}$ et al. Mice lacking endogenous IL-10-producing regulatory $B$ cells develop exacerbated disease and present with an increased frequency of Th1/Th17 but a decrease in regulatory T cells. J Immunol 2011; 186: 5569-5579.

41 Ding $Q$, Yeung M, Camirand G, Zeng Q, Akiba $\mathrm{H}$, Yagita $\mathrm{H}$ et al. Regulatory B cells are identified by expression of TIM-1 and can be induced through TIM-1 ligation to promote tolerance in mice. J Clin Invest 2011; 121: 3645-3656.

42 Shen P, Roch T, Lampropoulou V, O'Connor RA, Stervbo U, Hilgenberg E et al. IL-35-producing $B$ cells are critical regulators of immunity during autoimmune and infectious diseases. Nature 2014; 507: 366-370.

43 Matsumoto M, Baba A, Yokota T, Nishikawa H, Ohkawa Y, Kayama H et al. Interleukin-10-producing plasmablasts exert regulatory function in autoimmune inflammation. Immunity 2014; 41: 1040-1051.

44 Rafei M, Hsieh J, Zehntner S, Li M, Forner K, Birman E et al. A granulocyte-macrophage colony-stimulating factor and interleukin15 fusokine induces a regulatory $B$ cell population with immune suppressive properties. Nat Med 2009; 15: 1038-1045.

45 Maseda D, Candando KM, Smith SH, Kalampokis I, Weaver CT, Plevy SE et al. Peritoneal cavity regulatory B cells (B10 cells) modulate IFN- $\gamma+\mathrm{CD} 4+\mathrm{T}$ cell numbers during colitis development in mice. J Immunol 2013; 191: 2780-2795.

46 Yanaba K, Bouaziz JD, Matsushita T, Tsubata T, Tedder TF. The development and function of regulatory B cells expressing IL-10 (B10 cells) requires antigen receptor diversity and TLR signals. J Immunol 2009; 182: 7459-7472.

47 Candando KM, Lykken JM, Tedder TF. B10 cell regulation of health and disease. Immunol Rev 2014; 259: 259-272.

48 Yoshizaki A, Miyagaki T, DiLillo DJ, Matsushita T, Horikawa M, Kountikov El et al. Regulatory B cells control T-cell autoimmunity through IL-21-dependent cognate interactions. Nature 2012; 491: 264-268.

49 Evans JG, Chavez-Rueda KA, Eddaoudi A, Meyer-Bahlburg A, Rawlings DJ, Ehrenstein MR et al. Novel suppressive function of transitional 2 B cells in experimental arthritis. J Immunol 2007; 178: 7868-7878.

50 Maseda D, Smith SH, DiLillo DJ, Bryant JM, Candando KM, Weaver CT et al. Regulatory B10 cells differentiate into antibody-secreting cells after transient IL-10 production in vivo. J Immunol 2012; 188: 1036-1048.

51 Sun J, Wang J, Pefanis E, Chao J, Rothschild G, Tachibana I et al. Transcriptomics identify CD9 as a marker of murine IL-10-competent regulatory B Cells. Cell Rep 2015; 13: 1110-1117.

52 Shalapour S, Font-Burgada J, Di Caro G, Zhong Z, Sanchez-Lopez E, Dhar $\mathrm{D}$ et al. Immunosuppressive plasma cells impede T-celldependent immunogenic chemotherapy. Nature 2015; 521: 94-98. 
53 Kaku H, Cheng KF, Al Abed Y, Rothstein T. A novel mechanism of B-cell mediated immune suppression through adenosine production. J Immunol 2013; 190: 185-186.

54 Deaglio S, Dwyer KM, Gao W, Friedman D, Usheva A, Erat A et al. Adenosine generation catalyzed by CD39 and CD73 expressed on regulatory T cells mediates immune suppression. J Exp Med 2007; 204: 1257-1265.

55 Ganti S, Albershardt T, Iritani B, Ruddell A. Regulatory B cells accumulate in tumor-draining lymph nodes and promote tumor growth (TUM9P. 1015). J Immunol 2015; 194: 210-217.

56 Flores-Borja F, Bosma A, Ng D, Reddy V, Ehrenstein MR, Isenberg DA et al. CD19+CD24hiCD38hi B cells maintain regulatory T cells while limiting TH1 and TH17 differentiation. Sci Transl Med 2013; 5: 173ra23-173ra23.

57 Das A, Ellis G, Pallant C, Lopes AR, Khanna P, Peppa D et al. IL-10producing regulatory $B$ cells in the pathogenesis of chronic hepatitis B virus infection. J Immunol 2012; 189: 3925-3935.

58 de Masson A, Bouaziz JD, Le Buanec H, Robin M, O'Meara A, Parquet $\mathrm{N}$ et al. CD24hiCD27+ and plasmablast-like regulatory $\mathrm{B}$ cells in human chronic graft-versus-host disease. Blood 2015; 125: 1830-1839.

59 Lindner S, Dahlke K, Sontheimer K, Hagn M, Kaltenmeier C, Barth TF et al. Interleukin 21-Induced Granzyme B-Expressing B Cells Infiltrate Tumors and Regulate T Cells. Cancer Res 2013; 73: 2468-2479.

60 van de Veen W, Stanic B, Yaman G, Wawrzyniak M, Söllner S, Akdis DG et al. IgG 4 production is confined to human IL-10producing regulatory $B$ cells that suppress antigen-specific immune responses. J Allergy Clin Immunol 2013; 131: 1204-1212.

61 Siewe B, Stapleton JT, Martinson J, Keshavarzian A, Kazmi N, Demarais PM et al. Regulatory B cell frequency correlates with markers of HIV disease progression and attenuates anti-HIV CD8+ T cell function in vitro. J Leukoc Biol 2013; 93: 811-818.

62 Siewe B, Wallace J, Rygielski S, Stapleton JT, Martin J, Deeks SG et al. Regulatory B cells inhibit cytotoxic T lymphocyte (CTL) activity and elimination of infected CD4 T cells after in vitro reactivation of HIV latent reservoirs. PLoS One 2014; 9: e92934.

63 Bouaziz JD, Calbo S, Maho-Vaillant M, Saussine A, Bagot M, Bensussan A et al. IL-10 produced by activated human B cells regulates CD4+ T-cell activation in vitro. Eur J Immunol 2010; 40: 2686-2691.

64 Knippenberg S, Peelen E, Smolders J, Thewissen M, Menheere P, Tervaert JW et al. Reduction in IL-10 producing B cells (Breg) in multiple sclerosis is accompanied by a reduced naive/memory Breg ratio during a relapse but not in remission. J Neuroimmunol 2011; 239: 80-86.

65 Sarvaria A, Basar R, Mehta RS, Shaim H, Muftuoglu M, Khoder A et al. IL-10+ regulatory $B$ cells are enriched in cord blood and may protect against cGVHD after cord blood transplantation. Blood 2016; 128: 1346-1361.

66 Figueiró F, Muller L, Funk S, Jackson EK, Battastini AM, Whiteside TL. Phenotypic and functional characteristics of CD39high human regulatory B cells (Breg). Oncolmmunology 2016; 5: e1082703.

67 Kessel A, Haj T, Peri R, Snir A, Melamed D, Sabo E et al. Human CD19+ CD25 high $B$ regulatory cells suppress proliferation of CD4+ $T$ cells and enhance Foxp3 and CTLA-4 expression in T-regulatory cells. Autoimmun Rev 2012; 11: 670-677.

68 Tian J, Zekzer D, Hanssen L, Lu Y, Olcott A, Kaufman DL. Lipopolysaccharide-activated B cells down-regulate Th1 immunity and prevent autoimmune diabetes in nonobese diabetic mice. $\mathrm{J}$ Immunol 2001; 167: 1081-1089.

69 Moulin V, Andris F, Thielemans K, Maliszewski C, Urbain J, Moser M. B Lymphocytes Regulate Dendritic Cell (Dc) Function in Vivo Increased Interleukin 12 Production by DCs from B Cell-Deficient Mice Results in T Helper Cell Type 1 Deviation. J Exp Med 2000; 192: 475-482.

70 Wang WW, Yuan XL, Chen H, Xie GH, Ma YH, Zheng YX et al. CD19+ CD24hiCD38hiBregs involved in downregulate helper $\mathrm{T}$ cells and upregulate regulatory T cells in gastric cancer. Oncotarget 2015; 6 : 33486-33499.

71 Han S, Feng S, Ren M, Ma E, Wang X, Xu L et al. Glioma cell-derived placental growth factor induces regulatory B cells. Int J Biochem Cell Biol 2014; 57: 63-68.
72 Jahrsdörfer B, Blackwell SE, Wooldridge JE, Huang J, Andreski MW, Jacobus LS et al. B-chronic lymphocytic leukemia cells and other B cells can produce granzyme B and gain cytotoxic potential after interleukin-21-based activation. Blood 2006; 108: 2712-2719.

73 Bosma A, Abdel-Gadir A, Isenberg DA, Jury EC, Mauri C. Lipidantigen presentation by $\mathrm{CD} 1 \mathrm{~d}+\mathrm{B}$ cells is essential for the maintenance of invariant natural killer T cells. Immunity 2012; 36: 477-490.

74 Sorrentino R, Morello S, Forte G, Montinaro A, Vita GD, Luciano A et al. B cells contribute to the antitumor activity of $\mathrm{CpG}$ oligodeoxynucleotide in a mouse model of metastatic lung carcinoma. Am J Respir Crit Care Med 2011; 183: 1369-1379.

75 Jones HP, Wang YC, Aldridge B, Weiss JM. Lung and splenic B cells facilitate diverse effects on in vitro measures of antitumor immune responses. Cancer Immun 2008; 8: 4.

76 Kaliss N. Immunological Enhancement of Tumor Homografts in Mice A Review. Cancer Res 1958; 18: 992-1003.

77 Ran M, Witz IP. Tumor-associated immunoglobulins. Enhancement of syngeneic tumors by IgG2-containing tumor eluates. Int J Cancer 1972; 9: 242-247.

78 Brodt P, Gordon J. Natural resistance mechanisms may play a role in protection against chemical carcinogenesis. Cancer Immunol Immunother 1982; 13: 125-127.

79 Andreu P, Johansson M, Affara NI, Pucci F, Tan T, Junankar S et al. FcR $\gamma$ activation regulates inflammation-associated squamous carcinogenesis. Cancer Cell 2010; 17: 121-134.

80 Ammirante M, Luo JL, Grivennikov S, Nedospasov S, Karin M. B-cellderived lymphotoxin promotes castration-resistant prostate cancer. Nature 2010; 464: 302-305.

81 Yang C, Lee H, Pal S, Jove V, Deng J, Zhang W et al. B cells promote tumor progression via STAT3 regulated-angiogenesis. PloS One 2013; 8: e64159.

82 Barbera-Guillem E, Nelson MB, Barr B, Nyhus JK, May Jr KF, Feng L et al. B lymphocyte pathology in human colorectal cancer. Experimental and clinical therapeutic effects of partial B cell depletion. Cancer Immunol Immunother 2000; 48: 541-549.

83 Shah S, Divekar AA, Hilchey SP, Cho HM, Newman CL, Shin SU et al. Increased rejection of primary tumors in mice lacking $\mathrm{B}$ cells: Inhibition of anti-tumor CTL and TH1 cytokine responses by B cells. Int J Cancer 2005; 117: 574-586.

84 Park JM, Terabe M, Steel JC, Forni G, Sakai Y, Morris JC et al. Therapy of advanced established murine breast cancer with a recombinant adenoviral ErbB-2/neu vaccine. Cancer Res 2008; 68: 1979-1987.

85 Al-Shibli KI, Donnem T, Al-Saad S, Persson M, Bremnes RM, Busund LT. Prognostic effect of epithelial and stromal lymphocyte infiltration in non-small cell lung cancer. Clin Cancer Res 2008; 14: 5220-5227.

86 Nedergaard BS, Ladekarl M, Nyengaard JR, Nielsen K. A comparative study of the cellular immune response in patients with stage IB cervical squamous cell carcinoma. Low numbers of several immune cell subtypes are strongly associated with relapse of disease within 5 years. Gynecol Oncol 2008; 108: 106-111.

87 Kemp TJ, Moore JM, Griffith TS. Human B cells express functional TRAIL/Apo-2 ligand after CpG-containing oligodeoxynucleotide stimulation. J Immunol 2004; 173: 892-899.

88 Dong HP, Elstrand MB, Holth A, Silins I, Berner A, Trope CG et al. NK-and B-cell infiltration correlates with worse outcome in metastatic ovarian carcinoma. Am J Clin Pathol 2006; 125: 451-458.

89 Lundgren S, Berntsson J, Nodin B, Micke P, Jirström K. Prognostic impact of tumour-associated $B$ cells and plasma cells in epithelial ovarian cancer. J Ovarian Res 2016; 9: 21.

90 Domschke C, Schuetz F, Ge Y, Seibel T, Falk C, Brors B et al. Intratumoral cytokines and tumor cell biology determine spontaneous breast cancer-specific immune responses and their correlation to prognosis. Cancer Res 2009; 69: 8420-8428.

91 Horikawa M, Minard-Colin V, Matsushita T, Tedder TF. Regulatory B cell production of IL-10 inhibits lymphoma depletion during CD20 immunotherapy in mice. J Clin Invest 2011; 121: 4268-4280.

92 Bodogai M, Chang CL, Wejksza K, Lai J, Merino M, Wersto RP et al. Anti-CD20 antibody promotes cancer escape via enrichment of tumor-evoked regulatory B cells expressing low levels of CD20 and CD137L. Cancer Res 2013; 73: 2127-2138.

93 Minard-Colin V, Xiu Y, Poe JC, Horikawa M, Magro CM, Hamaguchi Y et al. Lymphoma depletion during CD20 immunotherapy in mice is 
mediated by macrophage FcyRI, FcyRIII, and FcyRIV. Blood 2008; 112: 1205-1213.

94 Aklilu M, Stadler WM, Markiewicz M, Vogelzang NJ, Mahowald M, Johnson $\mathrm{M}$ et al. Depletion of normal $\mathrm{B}$ cells with rituximab as an adjunct to IL-2 therapy for renal cell carcinoma and melanoma. Ann Oncol 2004; 15: 1109-1114.

95 Zhang Y, Morgan R, Chen C, Cai Y, Clark E, Khan WN et al. Mammary-tumor-educated B cells acquire LAP/TGF- $\beta$ and PD-L1 expression and suppress anti-tumor immune responses. Int Immunol 2016; 28: 423-433.

96 Zhang Y, Eliav Y, Shin SU, Schreiber TH, Podack ER, Tadmor T et al. $B$ lymphocyte inhibition of anti-tumor response depends on expansion of Treg but is independent of B-cell IL-10 secretion. Cancer Immunol Immunother 2013; 62: 87-99.

97 Olkhanud PB, Damdinsuren B, Bodogai M, Gress RE, Sen R, Wejksza K et al. Tumor-evoked regulatory $\mathrm{B}$ cells promote breast cancer metastasis by converting resting CD4+ T cells to T-regulatory cells. Cancer Res 2011; 71: 3505-3515.

98 Wejksza K, Lee-Chang C, Bodogai M, Bonzo J, Gonzalez FJ, Lehrmann $\mathrm{E}$ et al. Cancer-produced metabolites of 5-lipoxygenase induce tumor-evoked regulatory $\mathrm{B}$ cells via peroxisome proliferatoractivated receptor $\alpha$. J Immunol 2013; 190: 2575-2584.

99 Qian L, Bian GR, Zhou Y, Wang Y, Hu J, Liu X et al. Clinical significance of regulatory $B$ cells in the peripheral blood of patients with oesophageal cancer. Cent Eur J Immunol 2015; 40: 263-265.

100 Zhang C, Xin H, Zhang W, Yazaki PJ, Zhang Z, Le K et al. CD5 binds to interleukin- 6 and induces a feed-forward loop with the transcription factor STAT3 in B cells to promote cancer. Immunity 2016; 44: 913-923.

101 Liu J, Wang H, Yu Q, Zheng S, Jiang Y, Liu Y et al. Aberrant frequency of IL-10-producing B cells and its association with Treg and MDSC cells in Non Small Cell Lung Carcinoma patients. Hum Immunol 2016; 77: 84-89.

102 Zhou X, Su YX, Lao XM, Liang YJ, Liao GQ. CD19+ IL-10+ regulatory $B$ cells affect survival of tongue squamous cell carcinoma patients and induce resting $\mathrm{CD} 4+\mathrm{T}$ cells to $\mathrm{CD} 4+$ Foxp3+ regulatory $\mathrm{T}$ cells. Oral Oncol 2016; 53: 27-35.

103 Wei X, Jin Y, Tian Y, Zhang H, Wu J, Lu W et al. Regulatory B cells contribute to the impaired antitumor immunity in ovarian cancer patients. Tumour Biol 2016; 37: 1-8.

104 Zhang L, Tai YT, Ho M, Xing L, Chauhan D, Gang A et al. Regulatory $B$ cell-myeloma cell interaction confers immunosuppression and promotes their survival in the bone marrow milieu. Blood Cancer $\mathrm{J}$ 2017; 7: 547

105 Xiao X, Lao XM, Chen MM, Liu RX, Wei Y, Ouyang FZ et al. PD-1hi Identifies a Novel Regulatory B-cell Population in Human Hepatoma That Promotes Disease Progression. Cancer Discov 2016; 6: 546-559.

106 Lin JC, Shih YL, Chien PJ, Liu CL, Lee JJ, Liu TP et al. Increased percentage of $B$ cells in patients with more advanced hepatocellular carcinoma. Hum Immunol 2010; 71: 58-62.

107 Shao Y, Lo CM, Ling CC, Liu XB, Ng KT, Chu AC et al. Regulatory $B$ cells accelerate hepatocellular carcinoma progression via CD40/CD154 signaling pathway. Cancer Lett 2014; 355: 264-272.

This work is licensed under a Creative Commons Attribution-NonCommercial-NoDerivs 4.0 International License. The images or other third party material in this article are included in the article's Creative Commons license, unless indicated otherwise in the credit line; if the material is not included under the Creative Commons license, users will need to obtain permission from the license holder to reproduce the material. To view a copy of this license, visit http://creativecommons.org/licenses/by-nc-nd/4.0/

C) The Author(s) 2017 